\title{
EXCITON SPECTRA OF THE NANOSTRUCTURED ZINC OXIDE
}

\author{
V. Kapustianyk, M. Panasiuk, G. Lubochkova, B. Turko, V. Rudyk, M. Partyka, R. Serkiz, D. Voznyuk \\ Ivan Franko National University of Lviv, \\ Scientific-Technical and Educational Center of Low Temperature Studies, \\ 50, Drahomanov St., Lviv, Ukraine, UA-79005, \\ e-mail:kapustianik@yahoo.co.uk
}

(Received June 20, 2007; received in final form February 14, 2008)

\begin{abstract}
A simple two-step approach to produce $\mathrm{ZnO}$ nanorods and nanotubes by electron sputtering of the metallic zinc in vacuum and then oxidizing it to $\mathrm{ZnO}$ in air is reported. It has been found that the samples synthesised by this method exhibited much more intense exciton photoluminescence around $\sim 370 \mathrm{~nm}$ in comparison with the usual flat zinc oxide thin films. The clearly distinguished bands corresponding to localised exciton states and phonon replicas testify to quite high crystallinity of the obtained nanorods (nanotubes). The slight but noticeable blueshift (4 meV) in the near band edge luminescence for the sample with nanotubes in comparison with the samples with nanorods and flat films could reflect the quantum confinement effect.
\end{abstract}

Key words: zinc oxide, exciton, nanostructures, photoluminescense, quantum confinement effect.

PACS number(s): 61.82.Rx, 78.55.-m, 78.66.-w, 78.67.Bf

\section{INTRODUCTION}

$\mathrm{ZnO}$ has been widely used for many applications, for example, surface acoustic wave (SAW) devices and transparent electrodes due to its excellent piezoelectric and transparent properties [1,2]. Moreover, $\mathrm{ZnO}$ has recently attracted a considerable attention to the application of optoelectronic devices because of the improved excitonic properties compared to those of GaN. The notable properties of $\mathrm{ZnO}$ are a large bond strength and extreme stability of excitons, indicated by the stronger exciton binding energy $(\sim 60 \mathrm{meV})$, which is larger than that of $\mathrm{GaN}(\sim 24 \mathrm{meV})[3,4]$. The stability of the exciton makes $\mathrm{ZnO}$ a promising material for the realization of efficient excitonic lasing at room temperature [5]. ZnO has been extensively studied considering its potential applications in optoelectronics and photonic devices in the ultraviolet (UV) region [6,7] because of its strong exciton binding energy. Recently it has been found that the materials based on the zinc oxide due to the fast near-band-edge emission are potentially of interest for scintillation. In particular the $n$-doped $\mathrm{ZnO}$ :Ga manifests comparatively large luminosity and very short decay time. As a result this material is a potentially useful scintillator for detection of ionizing radiation at low temperatures [8].

Recently, some results concerning the effects of the thickness variation, substrate type and annealing on the crystallinity parameters, luminescent and optical properties of the zinc oxide thin films were reported $[9,10]$. The thin films were deposited on the glass and the amorphous quartz substrates by the standard RF-magnetron sputtering method using $\mathrm{ZnO}$ targets in the argon atmosphere. It has been found that the films deposited on the glass substrate manifest a clear size effect. Both the structural and the optical parameters show clear minima on their thickness dependences although at different values of thicknesses. It has been shown that the an- nealing of the comparatively thick $\mathrm{ZnO}$ films leads to an increase of the crystallite sizes that is followed by a considerable rise of the cathodoluminescence intensity. The corresponding model of the crystallite growth was proposed.

In recent years, the low-dimensional $\mathrm{ZnO}$ nanostructures, such as nanobelts, nanorods and nanowires, have attracted a great research interest for applications in the above mentioned directions. The growth of aligned $\mathrm{ZnO}$ nanorods and nanowires is considered to be a good candidate for scintillation, light emitting and field emission [11]. ZnO nanostructuers can be obtained by vapour transport reactions [12], wet chemical methods [13], including electrochemistry [14] and by the solid state reactions [15]. This work would be considered as a continuation of the above mentioned investigations. In the present work we studied the technological aspects of synthesis, structure and spectral properties of the zinc oxide nanostructures. The main attention was given to the study of the exciton states especially in the vicinity of liquid helium temperature. The exciton luminescence and absorption spectra are known to be quite informative for the study of the peculiarities of structure and energy transfer in the nanosystems.

\section{EXPERIMENT}

We report here a simple two-step approach to produce $\mathrm{ZnO}$ nanorods, i.e. preparing $\mathrm{Zn}$ polycrystalline film by electron sputtering of the metallic zinc in vacuum $\left(10^{-4}\right.$ Torr $)$ and then oxidizing it to $\mathrm{ZnO}$ nanorods in the air. This approach is very simple, catalyst free and is capable of growing $\mathrm{ZnO}$ nanorods at low substrate temperatures. The substrate temperature for the preparation of $\mathrm{Zn}$ nanorods was $\sim 200^{\circ} \mathrm{C}$ and that for the oxidation step was $850^{\circ} \mathrm{C}$. Applying the electric field 
$\left(U=600 \mathrm{~V}\left[3 \times 10^{4} \mathrm{~V} / \mathrm{m}\right]\right)$ during the oxidation of the film one could obtain the porous surface or nanotubes. A similar method was used in [16], but in that case the Zn nanorods had been already obtained at the first step. Besides, we used the electric field to change the morphology of the nanostructure.

The surface morphology of $\mathrm{ZnO}$ nanostructures was monitored by a scanning electron microscope (REMMA102-02, UKRAINE), equipped also with the sensors for the local chemical analysis.

The temperature evolution of the photoluminescence spectra near the intrinsic absorption edge was studied under excitation with a LGI-21 nitrogen laser at $337 \mathrm{~nm}$ emission wavelength and 10 ns pulse duration and power of $1 \mathrm{~kW}$.

\section{RESULTS AND DISCUSSION}

The micrographs of the surfaces covered with $\mathrm{ZnO}$ nanorods obtained using the scanning electron microscope are shown in Fig. 1. The nanorods mostly are aligned in the direction perpendicular to the surface (they are seen as bright dots or spots), whereas the nanorods aligned along other directions are clearly seen in the figures. It is necessary to note that in the case of sample No 3 beside the nanorods one could observe also the pores (nanotubes) in the surface. One can note that such a porous surface is formed due to the influence of electric field applied during the process of sample fabrication. As it follows from the data of the scanning electron microscopy, depending on the type of substrate (amorphous quartz or oriented sapphire) the obtained rods vary their height from 6 to $20 \mu \mathrm{m}$. Their radius was found to be in the framework from 30 to $75 \mathrm{~nm}$ (Table 1). These values are much larger in comparison with the Bohr radius of the exciton for $\mathrm{ZnO}(\sim 2 \mathrm{~nm})$ [17] that implies the possibility to observe only weak quantum confinement effects.

\begin{tabular}{|c|c|c|}
\hline \begin{tabular}{|c} 
Sample \\
No \\
\end{tabular} & Structure & $\begin{array}{c}\text { Average rod sizes: } \\
\text { diameter (height), nm }\end{array}$ \\
\hline 1 & $\overline{\mathrm{ZnO} / \text { quartz }}$ & $\begin{array}{l}\oslash \sim 60-130 \\
(L \sim 5000)\end{array}$ \\
\hline 2 & $\mathrm{ZnO} /$ sapphire & $\begin{array}{l}\oslash \sim 60-150 \\
(L \sim 20000)\end{array}$ \\
\hline 3 & $\mathrm{ZnO} /$ sapphire & $\begin{array}{c}\text { porous structure } \\
\text { (nanotubes) }\end{array}$ \\
\hline
\end{tabular}

Table 1. Characteristics of the zinc oxide samples.

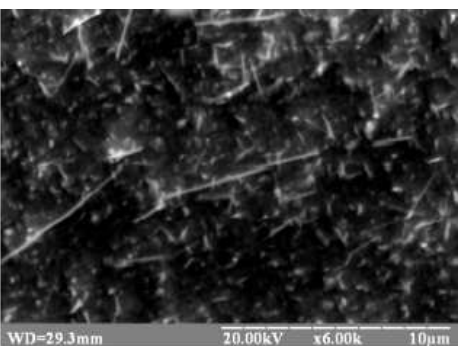

b)

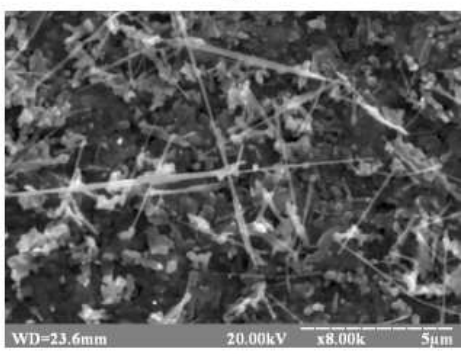

d)

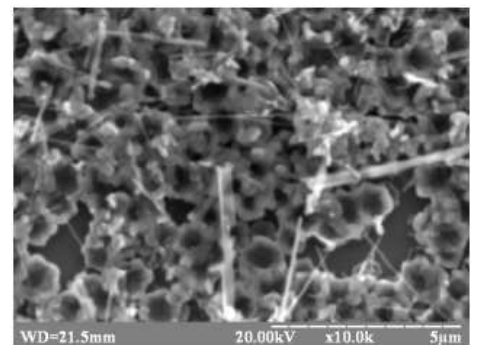

f)

Fig. 1. Micrographs of the surfaces with $\mathrm{ZnO}$ nanostructures: sample No 1 (a, b), No 2 (c, d) and No 3 (e, f). 
The $\mathrm{ZnO}$ nanorods synthesized by this method exhibited a much more intense exciton photoluminescence around $\sim 370 \mathrm{~nm}$ (Fig. 2a) and a much weaker one resulting from the stoichiometry defects at $\sim 500 \mathrm{~nm}$ in comparison with the usual flat thin films both at helium and room temperatures at the same excitation power [18]. This testifies to quite high material quality of the nanorods and is very important for the production of the UV light emitting devices. The UV bands in the absorption (Fig. 2b) and PL spectra of $\mathrm{ZnO}$ nanorods exhibit a clear structure connected with different exciton states and their phonon replicas. The corresponding excitation spectrum for $300 \mathrm{~K}$ is illustrated by Fig. $2 \mathrm{~b}$.

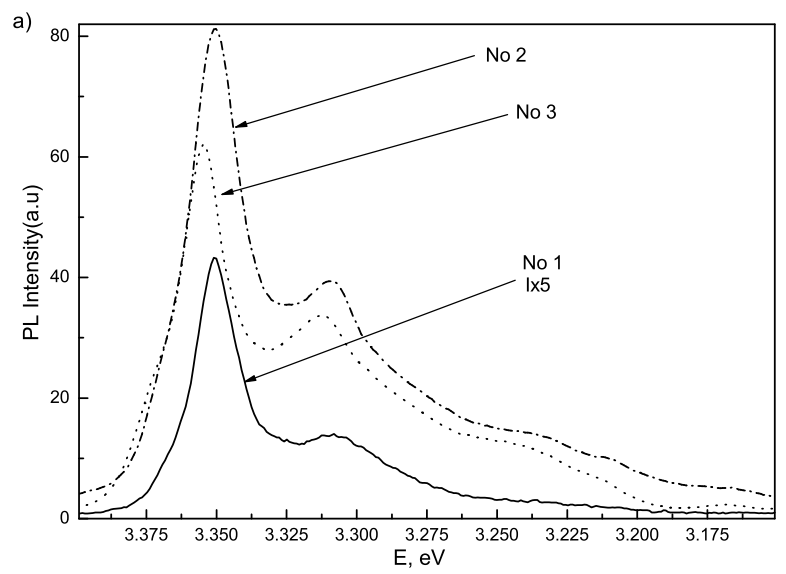

b)

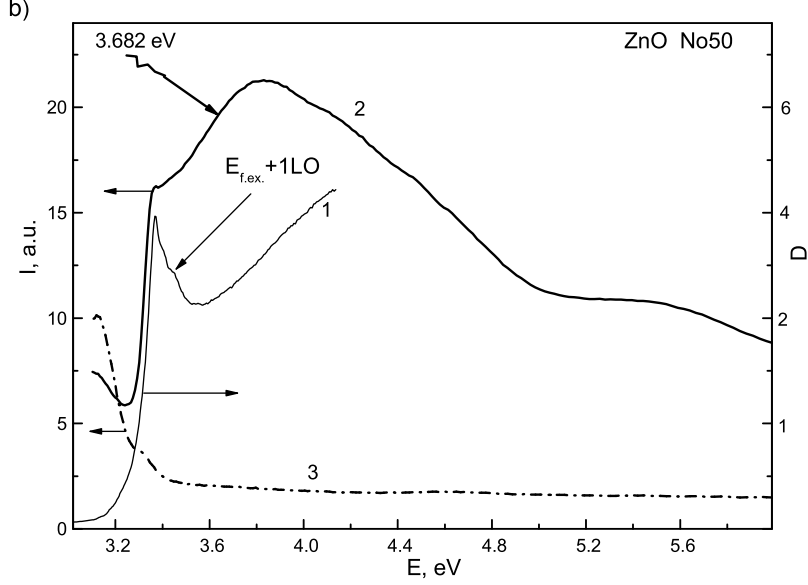

Fig. 2. a) - photoluminescence spectra of the $\mathrm{ZnO}$ nanostructures obtained at different conditions (notation as in Table 1) measured at $\mathrm{T}=80 \mathrm{~K}$; b) - correlation between absorption (1) and excitation $(2,3)$ spectra for sample No 1 measured at: 1-78 K, 2-78 K, 3-300 K.

The photoluminescence spectra were investigated over the temperature range of 7-300 K. Fig. 3, 4, 5 show the temperature evolution of the photoluminescence spectra for different samples. For $\mathrm{ZnO}$ rods the photoluminescence spectra are consistent with luminescence data reported for near band edge emission in the films obtained using RF magnetron sputtering [14,15].

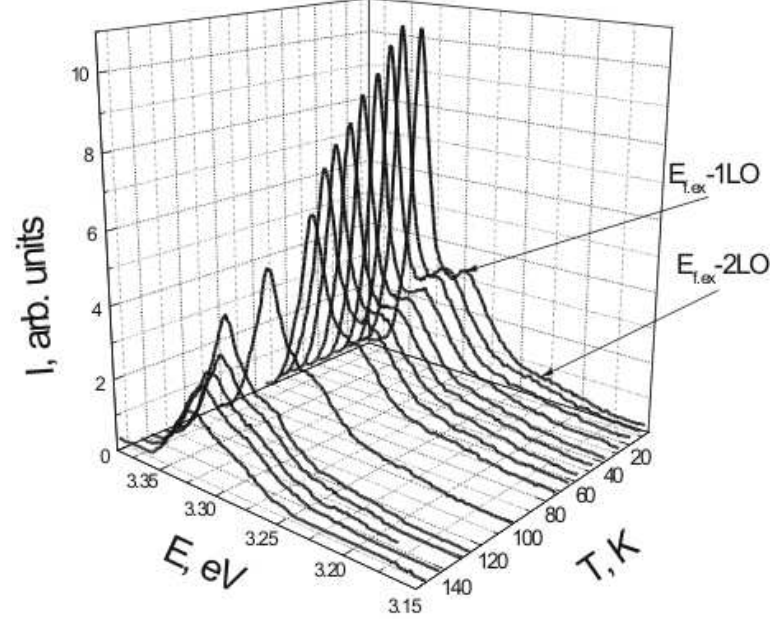

Fig. 3. The temperature evolution of the photoluminescence spectra of $\mathrm{ZnO}$ (Sample No 1). Temperatures in the top-down succession, K: 7, 12, 20, 29, 39, 48, 58, 65, 74, 101, 126, 131, 138, 143, 150 .

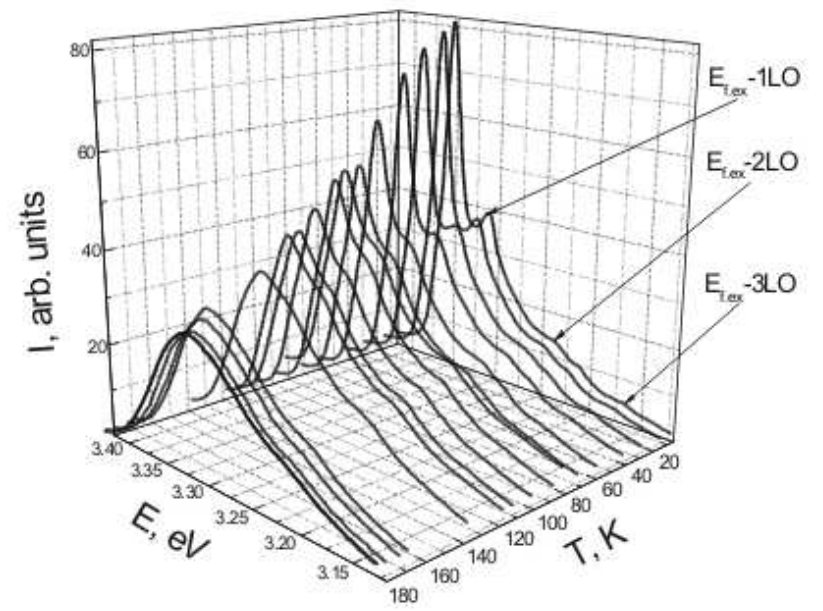

Fig. 4. The temperature evolution of the photoluminescence spectra of $\mathrm{ZnO}$ (Sample No 2). Temperatures in the top-down succession, $\mathrm{K}: 7,15,29,37,42,60,72,82,101,112$, 138, 169, 173, 180, 184, 185.

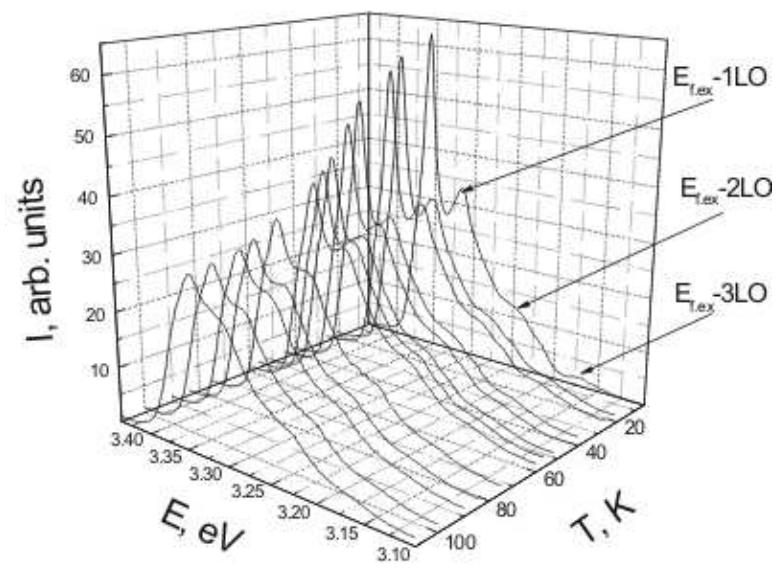

Fig. 5. The temperature evolution of the photoluminescence spectra of $\mathrm{ZnO}$ (Sample No 3). Temperatures in the top-down succession, K: $7,21,26,40,45,52,56,69,75,84$, 90, 100, 108 . 
The spectra shown in Fig. 2a possess a complex character. It should be noted that PL spectrum for the $\mathrm{ZnO}$ nanostructures differs from that for a bulk crystal [19]. In our case the most intensive band with the maximum at $3.352 \mathrm{eV}$ has to be related to the localized acceptorbound exciton transition $\left(\mathrm{A}^{0} \mathrm{X}\right)$, observed as $\mathrm{I}_{10}$ peak in [20]. This asymmetric band has a clear shoulder on the high-energy side. The position of the corresponding hidden peak as well as of the phonon replicas has been found using the method of derivative spectrophotometry [21]. The energy of this peak was found to be $3.373 \mathrm{eV}$ that is sufficiently close to the free exciton band characteristic of $\mathrm{ZnO}[22,23]$. The obtained exciton spectra are very similar to those for the samples obtained by the MOCVD method in [23]. The authors of this work have found the peak $\mathrm{A}^{0} \mathrm{X}$ at $3.353 \mathrm{eV}$. A small difference in the compared spectra, in particular, the broadening of the localized exciton peak and the first LO-phonon replica, may be explained by the presence of the neutral donor-bound exciton peak of the residual dopant (Ga amount up to 1 at. \% has been found by the energydispersive X-ray spectrometry method). As the temperature increases, the free and localised exciton emission bands shift to lower energies due to the temperature dependence of the bandgap. At lower energies a set of the equidistant peaks (from one to three depending on the sample) is observed. They could be related to the longitudinal optical phonon replicas (assigned as $n \mathrm{LO}$ ). It is necessary to note that the phonon replica is also observed in the absorption spectra (Fig. 2 b).

Slight but noticeable blueshift $(\sim 4 \mathrm{meV})$ of the near band edge luminescence peak $\left(E_{b . e x}\right)$ for sample No 3 in comparison with other samples would reflect the mentioned quantum confinement effect [24]. This means that under the influence of electric field during the process of sample fabrication one could obtain the elements of structure - pores or tubes - with the characteristic sizes much closer to the exciton Bohr radius than in other cases. This characteristic size first of all would be related to the thickness of the nanotube wall (see Fig. 1 e, f).

The characteristic energy of the LO phonon can be determined from the energy spacing between the exciton resonant lines and their LO phonon replicas. Using the method of the derivative spectrophotometry we have measured the energy distance from the free exciton peak to the first phonon replica. It was found to be equal $62 \mathrm{meV}$. This value does not coincide exactly with the LO phonon energy of $72 \mathrm{meV}$ for the bulk crystal [19]. Similarly to the authors of [25] such a discrepancy would be associated with the exciton-polaron coupling in $\mathrm{ZnO}$ nanostructures.

The temperature dependences of the energy positions of the corresponding peaks are presented in Fig. 6 . The most interesting information should be drawn from the temperature dependences of the intensities of the bands corresponding to the free $\left(I_{\text {f.ex }}\right)$ and localized $\left(I_{\text {b.ex }}\right)$ excitons, respectively. The first of them shows a slight growth at heating $(T>40 \mathrm{~K})$, whereas the second one is quenched with temperature (Fig. 7). Such a situation is connected with a thermal activation of the bound ex- citons. The band at $3.352 \mathrm{eV}$ (near $370 \mathrm{~nm}$ ) would be assigned to acceptor-bound-exciton $\left(\mathrm{A}^{0} \mathrm{X}\right)$ complexes. The temperature dependence of the integrated intensity $I_{\mathrm{b} \text {.ex }}$ of the $\left(\mathrm{A}^{0} \mathrm{X}\right)$ line could be expressed by the equation [26]:

$$
I(T)=\frac{I_{0}}{1+A \exp \left(-E_{a} / \kappa_{b} T\right)},
$$

where $E_{a}$ is the activation energy of the thermal quenching process, $\kappa_{b}$ is the Boltzmann constant, $I_{0}$ is the emission intensity at $T=0 \mathrm{~K}, T$ is a thermodynamic temperature and $A$ is a constant.

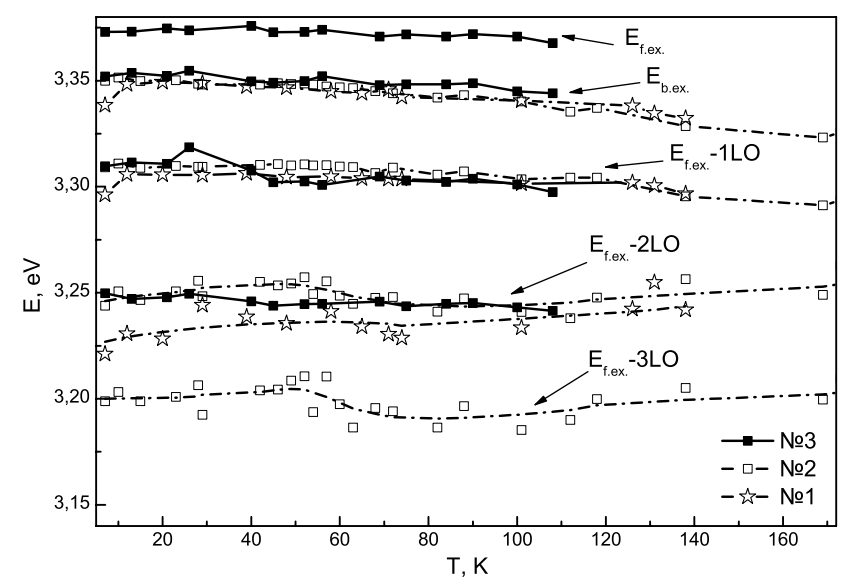

Fig. 6. The temperature evolution of the energy position of the maxima in the photoluminescence spectra of different $\mathrm{ZnO}$ samples.

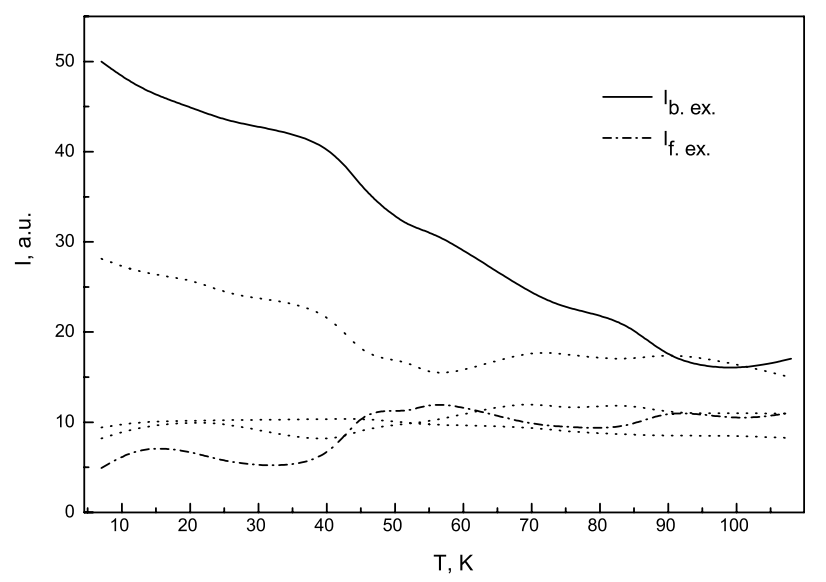

Fig. 7. The temperature dependence of intensities corresponding to different peaks in the photoluminescence spectra of $\mathrm{ZnO}$ nanotubes (Sample No 3). The assignment of the lines is clear from the text. The dot lines correspond to the intensities of the phonon replicas.

The corresponding activation energy obtained from the inverse temperature dependence of the photoluminescence intensity for sample No 3 (Fig. 8) was found to be $E_{a}=11 \mathrm{meV}$ (for the temperature range $T<40 \mathrm{~K}$ ). 


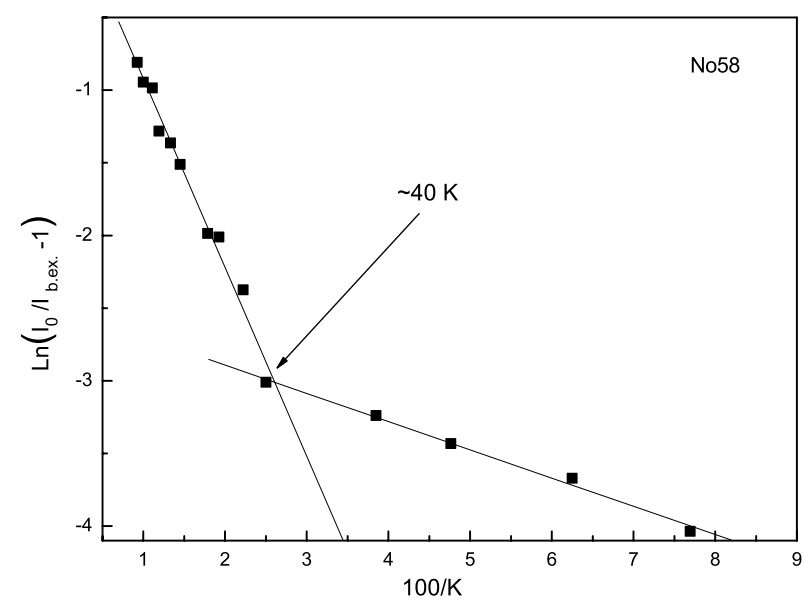

Fig. 8. Inverse temperature dependences of the luminescence intensity for the acceptor-bound exciton band for $\mathrm{ZnO}$ nanostructure (Sample No 3). Temperature - in K.

The temperature dependences of the photoluminescence parameters for other investigated samples were found to be very similar to those presented in Fig. 6, 7, 8 . This implies that the mechanisms of the exciton luminescence for all the considered samples are very close. All the investigated samples are characterized by a clear change of slope of the dependences $\ln \left(I_{0} / I-1\right)=f(1 / T)$ at the temperatures close to $T=40 \mathrm{~K}$. The values of the activation energy for the described process of thermal quenching were found to be equal: $E_{a}=20 \mathrm{meV}$ (for sample No 1) and $E_{a}=10 \mathrm{meV}$ (for sample No 2). The values of activation energy of thermal quenching obtained in our study are quite close to the results of Fonoberov et al [17]. They studied the recombination processes in the two types of nanostructures of different sizes. The activation energy for quantum dots was found to be $9 \mathrm{meV}$ and that for the nanoparticles with the diameter of $20 \mathrm{~nm}$ was equal to $14.3 \mathrm{meV}$. A small value of the activation energy in comparison with the bulk crystal the authors connected with the possibility of some additional coupling between the acceptors in the nanostructure ensemble. Besides, they also observed a sharp change of slope on the temperature dependence of the integral intensity of the same band, but around $70 \mathrm{~K}$. The appearance of such an anomaly was explained by the relocalization between the acceptor-bound exciton and neutral donorbound exciton complexes. A similar explanation would be valid in our case with the only difference that the temperature range where the considered phenomenon is observed is shifted toward lower temperatures. Such a shift first of all would be connected with the change of the characteristic sizes of the nanostructures.

\section{CONCLUSION}

We have proposed a simple two-step approach to produce $\mathrm{ZnO}$ nanorods and nanotubes, i. e. preparing $\mathrm{Zn}$ polycrystalline film by electron sputtering of the metallic zinc in vacuum $\left(10^{-4}\right.$ Torr $)$ and then oxidizing it to $\mathrm{ZnO}$ nanorods in the air. The samples synthesized by this method exhibited much more intense exciton photoluminescence around $\sim 370 \mathrm{~nm}$ and much weaker PL at $\sim 500 \mathrm{~nm}$ in comparison with the usual flat thin films both at helium and room temperatures. This fact testifies to quite high material quality and crystallinity of the nanorods (nanotubes) that is very important for the production of the UV light emitting devices. The UV luminescence spectra of $\mathrm{ZnO}$ nanostructures at different temperatures were interpreted. The most intensive band with the maximum at $3.352 \mathrm{eV}$ has been related to the localized acceptor-bound exciton transition $\left(\mathrm{A}^{0} \mathrm{X}\right)$. A slight but noticeable blueshift $(4 \mathrm{meV})$ in the near band edge luminescence for the sample with nanotubes in comparison with those with nanorods and flat films [13] could reflect the quantum confinement effect. The application of the electric field during the sample preparation leads to the formation of the structure with nanotubes.
[1] C. R. Gorla, N.W. Emanetoglu, S. Liang, W. E. Mayo, Y. Lu, M. Wraback, H. Shen, J Appl. Phys. 85, 2595 (1999).

[2] T. Minami, T. Yamamoto, T. Miyata, Thin Solid Films 63, 366 (2000).

[3] P. Zu, Z. K. Tang, G. K. L. Wong, M. Kawasaki, A. Ohtomo, H. Koinuma, Y. Segawa, Solid State Commun. 103, 459 (1997).

[4] D. C. Reynolds, D. C. Look, B. Jogai, H. Morko, Solid State Commun. 103, 643 (1997).

[5] D. M. Bagnall, Y. F. Chen, M. Y. Shen, Z. Zhu, T. Goto, T. Yao, J. Cryst. Growth 184, 605 (1998).

[6] D. M. Bagnall, Y. F. Chen, Z. Zhu, T. Yao, S. Koyama, M. Y. Shen, T. Goto, Appl. Phys. Lett. 70, 2230 (1997).

[7] X. L. Guo, J. H. Choi, H. Tabata, T. Kawai, Jpn. J. Appl. Phys. 40, 177 (2001).

[8] S. Derenzo, M. Weber, M. Klintenberg, Nucl. Instrum. and Meth. in Phys. Res. A 486, 214 (2002).

[9] V. Kapustianyk, B. Turko, A. Kostruba, Z. Sofiani, S. Dabos-Seignon, B. Barwinski, Yu. Eliyashevskyi, B. Sahraoui, Optics Commun. 269, 346 (2007).

[10] M. R. Panasiuk, B. I. Turko, V. B. Kapustyanyk, G. A. Lubochkova, V. P. Rudyk, A. P. Vaskiv, V. M. Davydov, Functional Materials 12, 746 (2005).

[11] Y. W. Heo, D. P. Norton, L. C. Tien, Y. Kwon, B. S. Kang, F. Ren, S. J. Pearton, Materials Science and Engineering 47, 1 (2004).

[12] S. L. Mensah, V. K. Kayastha, I. N. Ivanov, D. B. Geohegan, Y. K. Yap, Appl. Phys. Lett. 90, 113108 (2007).

[13] Q. Li, V. Kumar, Y. Li, H. Zhang, T. J. Marks, R. P. H. Chang, Chemistry of Materials 17, 1001 (2005).

[14] M. Lai, D. J. Riley, Chemistry of Materials 18, 2233 (2006).

[15] C.-F. Jin, X. Yan, W.-W. Ge, J.-M. Hong, X.-Q. Xin, 
Nanotechnology 14, 667 (2003).

[16] J. Liu, Z. Zhang, X. Su, Y. Zhao, J. Phys. D: Appl. Phys. 38, 1068 (2005).

[17] V. A. Fonoberov, K. A. Alim, A. A. Balandin, F. Xiu, J. Liu, Phys. Rev. B 73, 165317 (2006).

[18] N. Zhaoyuan, L. Huoguan, Plasma Science and Technology 7, 2665 (2005).

[19] U. Ozgur, Ya. I. Alivov, C. Liu, A. Teke, M.A. Reshchikov, S. Doğan, V. Avrutin, S.-J. Cho, and H. Morkocd, J Appl. Phys. 98, 41301 (2005).

[20] B. K. Meyer, H. Alves, D. M. Hofmann, W. Kriegseis, D. Forster, F. Bertram, J. Christen, A. Hoffmann, M. Straburg, M. Dworzak, U. Haboeck, A.V. Rodina,
Phys. Stat. Sol.(b) 241, 231 (2004).

[21] T. R. Griffiths, K. King, H.v.St.A. Hubbard, M.-J. Schwing-Weill, J. Meullemeestre, Anal. Chim. Acta 143, 163 (1982).

[22] D. G. Thomas, J. Phys. Chem. Solids 15, 86 (1960).

[23] J. Dai, H. Su, L. Wang, Y. Pu, W. Fang, F. Jiang, J. Cryst. Growth 290, 426 (2006).

[24] Phosphor Handbook, edited by S. Shionoya, W. M. Yen, Boca Raton, CRC Press, 921 p. (1998).

[25] H. Hsu, W. Hsieh, Solid State Commun. 131, 371 (2004).

[26] X. T. Zhang, Y. C. Liu, Z. Z. Zhi, J. Y. Zhang, Y. M. Lu, D. Z. Shen, W. Xu, X. W. Fan, X. G. Kong, J. Lumin. 99, 149 (2002).

\section{ЕКСИТОННІ СПЕКТРИ НАНОСТРУКТУРОВАНОГО ОКСИДУ ЦИНКУ}

В. Капустяник, М. Панасюк, Г. Лубочкова, Б. Турко, В. Рудик, М. Партика, Р. Серкіз, Д. Вознюк Науково-технічний і навчальний центр низъкотемпературних досліджень Лъвівсъкий національний університет імені Івана Франка вул. Драгоманова, 50, Лъвів, Україна, UA-79005

Запропоновано простий двоступеневий метод отримання наностовпчиків та нанотрубок ZnO вакуумним електронним напиленням тонкої плівки металічного цинку з наступним ї̈ окисненням до ZnO на повітрі. Виявлено, що зразки, синтезовані цим методом, мають інтенсивнішу фотолюмінесценцію в околі 370 нм порівняно зі звичайними тонкими плівками оксиду цинку. Чітко виражені смуги, що відповідають станам локалізованого екситона та фононним повторенням, засвідчують доволі високий ступінь кристалічності отриманих наностовпчиків (нанотрубок). Невелике, але помітне зміщення (4 меВ) у бік вищих енергій прикрайової люмінесценції для зразка з нанотрубками порівняно зі зразками з наностовпчиками та тонкими плівками можна пояснити квантовим розмірним ефектом. 